\title{
NIH aims at 'glass ceiling'
}

\section{Washington}

CONCEDING for the first time that women's health cannot be improved without also improving conditions for women scientists, the US National Institutes of Health (NIH) is expanding its new women's health initiative to try to topple some of the barriers that women face in research.

This week NIH held a two-day hearing on the problem of the 'glass ceiling' - the invisible wall of discrimination that many women scientists run into in their researcher careers. Earlier in the month, NIH released a study on women researchers* showing that the percentage of women applying for biomedical grants is growing

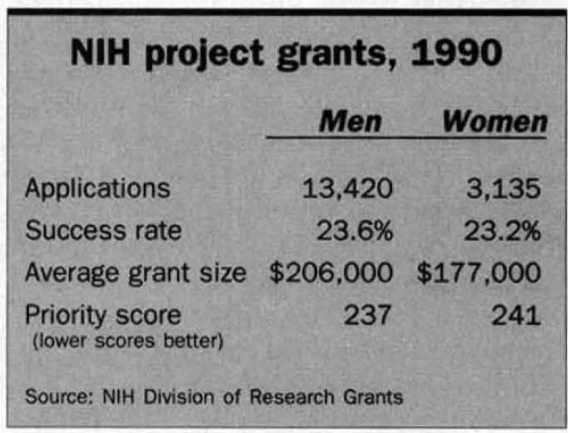

although men, on average, still receive larger grants. And in June, the NIH Office of Research on Women's Health will hold a workshop to propose new programmes to help women scientists, a move that marks a new direction for an office that only a year ago was refusing even to consider the issue.

Credit for the shift goes to a 1990 study by the congressional General Accounting Office (GAO), which found women badly underrepresented in NIH-sponsored clinical trials. That, along with a string of women's health scandals such as the Dalkon Shield and breast implants, prompted legislators to give the agency more than $\$ 30$ million last year for new research on women's health.

Although NIH had hoped to keep professional issues out of the new programme, the first public meeting of the Office of Research on Women's Health, held last September, demonstrated that the matter could not be ignored. Despite warnings that the meeting should be concerned solely with health research, virtually all the questions and comments were about the problems faced by women researchers, says Ruth Kirschstein, director of the NIH Institute of General Medical Science and the former acting director of the women's health office.

"They were quite clear," Kirschstein says of those who attended that meeting. "As long as there are not enough women doing biomedical research, there will not be enough emphasis on women's health - they go hand in glove."
Vivian Pinn, who last fall became director of the NIH women's health office, says that improving the lot of women researchers has become an "implied mandate" for the office. "If we want women's health research to become institutionalized, we need to move more women researchers into the position of saying what's done."

Women still have a way to go, she points out. Although they make up 39 per cent of all medical school students, women account for only 21.5 per cent of the faculty of those schools and just four per cent of medical school department chairs.

Pinn hopes that this week's hearings and the workshop in June will produce several concrete suggestions on how to increase those numbers. One idea already under consideration is a new tenure system that takes child-bearing and family care into account. Her office is also thinking about creating a national database of available faculty positions and research opportunities to give women researchers a fairer shot at jobs and grants.

Although there is now plenty of money for research on women, no NIH grants are targeted for women researchers themselves. Even a $\$ 500$ million, ten-year study on women's health is controlled mostly by the individual NIH institutes, rather than the women's health office. Nevertheless, Pinn says, direct funding for women researchers is "something we can argue for."

Another issue facing the NIH is their own treatment of women. Last year, 194 complaints of sexual discrimination and other gender-related mistreatment were filed against the institutes, according to Self Help for Equal Rights (SHER), an independent organization campaigning for the rights of women and other employee of NIH. At least four lawsuits charging sex discrimination or harassment at $\mathrm{NIH}$ are pending.

Pinn acknowledges the problem, but says it is primarily an issue for the agency's equal employment officials. "We have to discuss issues of sexual harassment and gender discrimination [at NIH] , but that is not our main focus," Pinn says.

Those issues nevertheless may surface within the women's health programme. Although SHER president Billie Mackay applauds Bernadine Healy, the NIH director, for expanding the scope of the programme, she promises more public battles with the agency as long its conduct generates lawsuits. Despite the NIH's newfound sensitivity, SHER claims, the agency still has "harassers and discriminators" in virtually every branch of its management tree. Christopher Anderson

* Women in NIH Extramural Grant Programs: 1981-1990; NIH Division of Research Grants, 1992.

\section{Goodwin stumbles}

Washington

A FEDERAL health administrator has been demoted after members of Congress condemned his public comments comparing the conduct of young, inner-city minority males to the behaviour of rhesus monkeys in the wild. But the drama may not be over: questions remain about the wisdom of his running the agency that funds much of that research, and critics want him removed entirely from public office.

Frederick Goodwin, for the past three years the administrator of the Alcohol, Drug Abuse and Mental Health Administration (ADAMHA), resigned last week after apologizing for drawing parallels between hyperaggressive and hypersexual behaviour among male primates and the rising violence among inner-city youths as a result of what he called "a loss of civilizing factors".

Goodwin was immediately named director of the National Institute of Mental Health (NIMH), one of the three institutes that comprise ADAMHA. Goodwin said in his letter of resignation to President Bush that he was stepping down because of his wish to "defuse" an issue that "is being exploited politically". Goodwin's boss, Louis Sullivan, secretary of the US Department of Health and Human Services, said last week that he was speeding up a transition planned for later in the year.

The change is a bit more hasty than Goodwin and Sullivan suggest. Goodwin was to take over NIMH as part of a reorganization of federal health agencies, with the research components of NIMH and its sister institutes of drug abuse and alcohol abuse being subsumed by the US National Institutes of Health. But such a reorganization now appears unlikely. It is opposed by the chairmen of the two committees in Congress that oversee these agencies both of whom have questioned Goodwin's fitness for continued government service.

Scientists who rely on NIMH for funding are concerned about whether congressional unhappiness with Goodwin will cut into support for the agency's scientific agenda. "How can he be an advocate for his agency's budget if he couldn't be effective one step higher up?" wonders Alan Kraut, executive director of the American Psychological Society.

Researchers are also troubled by the way Goodwin depicted the underlying research. Felton (Tony) Earls, a Harvard psychiatrist who is a member of the NIMH advisory board at which Goodwin made his remarks last month, says he was "shocked" by Goodwin's description of such aggressive behaviour by primates as normal. Another board member, Dominick Purpura of the Albert Einstein College of Medicine, says that Goodwin "knows better than to forget about five million years of evolution." Jeffrey Mervis 